\title{
A Probe into the Path of Internalization of Green Development Concept in China's Commercial Banks Credit System
}

\author{
Chen Jie* Chen Yuee Zhang Hualun \\ School of Public Affairs, University of Science and Technology of China
}

\begin{abstract}
Since the mid-1990s, China's green credit business has witnessed great progress. Generally speaking, the proportion of green credit balance in total loans, however, is still quite low. This paper believes that on top of some objective reasons that the green credit business started late and the industrial structure is less strong, the subjective awareness of green development and environmental responsibility of banking financial institutions is weak, systematic green credit policy is deficient and internal control mechanism is imperfect, which are the main reasons for constraining the development of green credit business. Therefore, the current paper explores the feasible path to promote the rapid development of green credit business from the perspective of the internalization of green development concept in the bank credit system. It mainly consists of three parts: firstly, it expounds the concept of green credit from the perspective of the conception and definition of internalized green credit development; secondly, it analyzes the status quo of China's green credit development and its functional reasons; finally, with the three paths of proposing a green credit policy, establishing a green development concept and strengthening internal mechanisms of management and control, we integrate the green development concept into the bank's green credit system for the purpose of promoting the development of green credit business in banking financial institutions.
\end{abstract}

Keywords: green credit, credit policy, path analysis

DOI: $10.7176 / \mathrm{PPAR} / 9-4-02$

Publication date: April $30^{\text {th }} 2019$

\section{Introduction}

In 1995, China promulgated the "Notice on Issues Concerning the Implementation of Credit Policies and Strengthening Environmental Protection Work", which first proposed that financial institutions should consider the environmental impact of the production activities of loan companies. In 2007, the People's Bank of China, the China Banking Regulatory Commission and the State Environmental Protection Administration jointly promulgated the "Opinions on Implementing Environmental Protection Policies and Regulations to Prevent Credit Risks", which clarified the credit environmental protection requirements and provided a policy basis for the development of green credit. In 2012, the Notice of the China Banking Regulatory Commission on Printing and Distributing Green Credit Guidelines required financial institutions to strengthen green credit capacity and risk management and control capabilities, and China's green credit stepped into a new phase of development. In recent years, China's green credit business has continued to develop. Regardless of the loan constraints of "two highs and one surplus", or the development of energy-saving and environmentally-friendly loans, the expected effect of the green credit policy has been basically achieved. However, in general, the proportion of green credit balance to total loan is still low, partly due to objective factors such as the late start of China's green credit business and weak industrial structure, but more importantly, for banking financial institutions, their weak subjective awareness of green development and environmental responsibility, lack of a systematic green credit policy and lack of internal control mechanisms are attributable[1]. In view of the important role of green credit in promoting the transformation and upgrading of China's economic structure and the construction of a two-type society, this paper will explore the feasible path to promote the rapid development of green credit business from the perspective of the conception of internalization of green credit in the banking credit system.

\section{The conception of green credit}

The practice of green credit in foreign countries is called sustainable financing or environmental financing. It refers to the introduction of environmental audit procedures by banks in the credit process to promote credit support for enterprises and projects that pass their environmental audits, and to suspend or completely prohibit the provision of any form of credit support for the enterprises that have failed in their environmental audits in order to establish a preventive mechanism for environmental protection and control the development of enterprises that are seriously polluting the environment from the source. Some Chinese scholars summarized the green credit, according to the "Opinions on Implementing Environmental Protection Policies and Regulations to Prevent Credit Risks", as financial institutions such as commercial banks and policy banks, based on national environmental, economic and industrial policies, on research and development, production and pollution control[2]. Facilities, engaged in ecological protection and construction, development and utilization of energy, enterprises or institutions engaged in circular economy production, green manufacturing and ecological 
agriculture provide loan support and implement preferential low interest rates, while investment loans and working capital for pollution-producing new projects Policy measures to limit loan quotas and implement punitive high interest rates.

This paper believes that the green credit business is banks' autonomous behavior, which reflects not only the external regulatory requirements but more importantly, banks' own intentions and practices. Taking all these into consideration, the green credit discussed in this paper refers to a series of activities: financial banking institutions classify production units or service providers within the framework of national industry, energy conservation, environmental protection, and green credit policies, and conduct credit business according to the results of green category and comprehensive evaluation of credit rating.

\section{Status Quo and Causes of China's Green Credit Development}

Since the promulgation of the "Notice on Implementing Credit Policies and Strengthening Environmental Protection Work" in 1995, China has successively issued a series of policy documents related to green credit. It has clarified the credit control requirements for high-pollution, high-energy-consuming and high-emission industries, encouraged the development of green, low-carbon, and circular economy credit businesses, and pointed out the development direction for the Chinese banks' green credit. Up to the end of 2015, the balance of green credit of banking financial institutions was 8.08 trillion yuan, of which the balance of green credit of 21 major banking financial institutions reached 7.01 trillion yuan, an increase of $16.42 \%$ from the end of 2014 . In 2015 , the balance of the "two high and one surplus" industry loans of banking financial institutions was 1.8 trillion yuan, a decrease of 0.48 trillion yuan compared with 2014, and the balance of energy conservation and environmental protection loans was 232 million yuan, financing a total of 23,100 energy conservation and environmental protection projects. In recent years, China's green credit business developed progressively. In view of the loan constraints of "two highs and one surplus", and the development of energy-saving and environmentally-friendly loans, the expected effect of the green credit policy has been basically achieved. However, there is also a problem of low green credit. As shown from the table 1 below, in the three years of 2014, 2015 and 2016, although the green credit balance of the five major banks showed a year-on-year growth trend, in general, the proportion of the five major banks' green credit balance in the total loan amount is still not high. The reasons can be summarized as the following three points:

Table1: Total green credit and loan figures of the five major banks in 2014-2016

Unit: 100 million yuan

\begin{tabular}{|c|c|c|c|c|c|c|c|c|c|}
\hline $\begin{array}{c}\text { Balance } \\
\text { Five Major Banks }\end{array}$ & \multicolumn{3}{|c|}{2014} & \multicolumn{3}{c|}{2015} & \multicolumn{3}{c|}{2016} \\
\cline { 2 - 10 } & Green & $\begin{array}{c}\text { Total } \\
\text { Loan }\end{array}$ & Percentage & $\begin{array}{c}\text { Green } \\
\text { Credit }\end{array}$ & $\begin{array}{c}\text { Total } \\
\text { Loan }\end{array}$ & Percentage & $\begin{array}{c}\text { Green } \\
\text { Credit }\end{array}$ & $\begin{array}{c}\text { Total } \\
\text { Loan }\end{array}$ & Percentage \\
\hline $\begin{array}{c}\text { Industrial and } \\
\text { Commercial Bank } \\
\text { of China }\end{array}$ & 8117 & 110263 & $7.36 \%$ & 9146 & 119335 & $7.66 \%$ & 9786 & 130568 & $7.49 \%$ \\
\hline Agricultural Bank & 4724 & 80981 & $5.83 \%$ & 5431 & 89099 & $6.10 \%$ & 6494 & 97196 & $6.68 \%$ \\
\hline Bank of China & 3010 & 84833 & $3.55 \%$ & 4123 & 91359 & $4.51 \%$ & 4673 & 99734 & $4.69 \%$ \\
\hline Construction Bank & 4871 & 94745 & $5.14 \%$ & 7336 & 104851 & $7.00 \%$ & 8892 & 117570 & $7.56 \%$ \\
\hline $\begin{array}{c}\text { Bank of } \\
\text { Communications }\end{array}$ & 1440 & 34317 & $4.20 \%$ & 2048 & 37220 & $5.50 \%$ & 2412 & 41030 & $5.88 \%$ \\
\hline
\end{tabular}

Source: Five major banks 2014-2016 annual report and 2014-2016 social responsibility report

- China's green credit business started late. As early as 1974, the Federal Republic of Germany established the world's first policy-based environmental protection bank, which is responsible for providing preferential loans for investment in environmental protection projects. Green credit business in China was gradually developed after the promulgation of the "Notice on Implementing Credit Policies and Strengthening Environmental Protection Work" (1995). Due to its weak foundation and late initiation, China's green credit policies, systems, and management mechanisms are far from perfect, and green credit products are not rich enough, all of which make certain restrictive effects on the development of green credit business.

- The industrial structure is relatively weak. Since the reform and opening up, China's rapid economic development and the cost advantage of mass production have earned China the title of "world factory", but this comparative advantage is largely based on cheap labor, the predatory development of resources and low environmental costs. The competitive advantage of the Chinese industry is mainly concentrated on the low-value-added non-core component manufacturing, labor-intensive assembly, high-energy and highpollution industries, and is at the bottom of the global value chain. In recent years, China's industrial structure transformation and upgrading have achieved certain results. The emerging technologies, high-end manufacturing, energy conservation, and environmental protection industries continue to develop rapidly, 
but in terms of the number and scale of these enterprises, the gap with developed economies is still selfevident.

- The bank's awareness of green development and environmental responsibility is still insufficient. Although under the framework of China's green credit policy, banks have the obligation to fulfill their environmental responsibilities, in practice, green development and environmental responsibility awareness are not fully integrated into the bank's vision, mission and development strategy, making the bank's green credit business just simply implement the nation's industrial policies and regulatory requirements, without inherent enthusiasm to promote the rapid development of green credit business. Therefore, banks' initiatives to establish a green credit policy for the shaping of the all-around business landscape and improve the internal control process are not strong, which has a negative impact on the development of green credit business.

Things changes are attributed to the interaction between internal and external factors. External factors act through internal factors, and the change and development of things are fundamentally determined by their own internal factors. Based on the above analysis, this paper believes that only by integrating the green development concept into the bank's green credit system and realizing the overall "greening" of banks' philosophy, credit policy, and management and control mechanism, can we continue to promote the sound development of China's green credit business.

\section{A feasible path to integrate the green development concept into the bank credit system}

In view of the fact that external factors can be affected by many factors, and cannot be optimized in a short period of time, this paper mainly focus on, from the perspective of banks themselves, how to integrate the concept of green development into the bank credit system by developing green development concepts, making green credit policies, and strengthening internal control mechanisms.

\subsection{Developing a green development concept}

First of all, the vision, mission, and development strategy of green development should be embedded within the bank, and the green development concept and awareness of environmental responsibility should be incorporated into the bank development process from the strategic perspective. Banks can set up a green financial committee, organize and carry out centralized management, systematically introduce and integrate green supporting policies, and promote the leapfrog development of green credit business. Second, the promotion and training of green development should be continuously strengthened. It is necessary to carry out the popular publicity and education of the green development concept for all employees through banks' internal training system, and more specifically, to carry out professional training for the design of featured content by different groups. In addition, the training of green concepts should be combined with practical work such as credit policies and business knowledge to deepen employees' understanding of green development and promote the ability of green credit business.

\subsection{Establishing a green credit policy}

Incorporating the green development concept into the credit system needs banks to re-examine the credit target group from green and environmental perspective and classify them at a green level. On this basis, different credit policies are applied according to the green level and credit rating of the target.

4.2.1 Green level classification

The environmental responsibility of enterprises mainly includes: reducing the consumption of non-renewable resources, recycling used materials, reducing pollutant emissions, and developing energy-saving, lowconsumption, non-toxic products. According to the performance of enterprise resource conservation and environmental protection, they are divided into four categories:

Class I: Energy-saving and environment-friendly innovative enterprises or projects. It mainly includes emerging technology enterprises or projects with energy-saving and environmental protection effects, or enterprises or projects that are technologically advanced and capable of saving energy and reducing pollutant emissions after upgrading technology; national energy-supported key energy-saving and environmental protection projects, and technically feasible, economically energy management projects, etc.

Class II: Non-contaminated or non-restricted enterprises or projects that meet relevant national standards. At present, most of the stock credits in bank credit grants can be classified into this category, which is neither pollution nor energy-saving and environmentally-friendly innovation enterprises or projects, such as infrastructure, tertiary industry, and manufacturing industry.

Class III: Enterprises or projects with low pollution and low energy consumption, or with high pollution and high energy consumption, but meeting the national energy conservation and emission reduction standards. It mainly includes enterprises and projects with high pollution and high energy consumption and meeting or exceeding the relevant national standards, such as chemical industry, steel industry, non-ferrous metal industry, cement industry, and paper industry. 
Class IV: Highly polluting and energy-intensive projects that are explicitly eliminated or restricted by the state. It mainly includes the restricted and eliminated categories in the National Industrial Structure Adjustment Guidance Catalogue and the projects and enterprises listed in the national elimination of backward production capacity; the steel, cement, non-ferrous metals and ferroalloys, coke, calcium carbide, and the announced projects and enterprises that have announced by Ministry of Industry and Information Technology to eliminate backward production capacity in the paper-making, tanning, printing and dyeing industries; projects and enterprises that have not met the national environmental protection standards, and projects and enterprises that have been announced and identified by the relevant state departments with excessive energy consumption and pollution problems. In addition, it also includes some industries with severe overcapacity.

What needs to be emphasized here is that the green level classification of bank credit objects is a relative concept. With the process of China's economic restructuring and upgrading, some industry-related restrictions and standards of elimination will continue to upgrade, and the classification of enterprises or projects in the scope at the green level will be adjusted. In addition, the development status of each enterprise is dynamic, and the green level classification of the enterprise will also change with the evolution in its technical level and product performance.

4.2.2 Green credit policy

At present, banks have not yet established a credit rating system that incorporates the green development concept, and the development of the green credit rating system is difficult and takes a long time. In the short term, banks still have to use the existing credit rating system to rate companies or projects. Therefore, this paper conducts a comprehensive analysis of enterprises or projects based on credit ratings and green categories and adopts corresponding credit policies or strategies for different two-dimensional combinations.

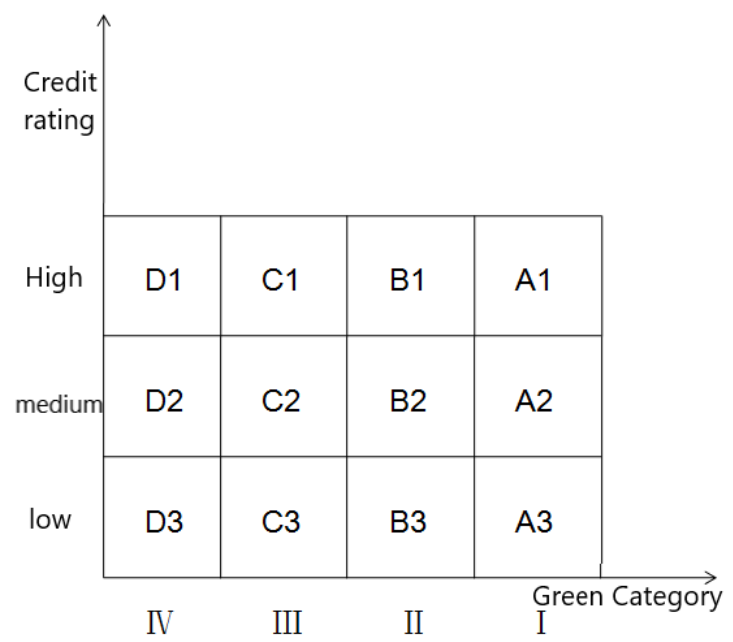

Figure 1: Two-dimensional analysis of green categories and credit ratings

The bank's green credit policy should utilize the analysis of the future 1 economic situation, industrial policy trends, inter-bank credits, and bank's stock credit and project reserves, rely on customer credit ratings and green categories, to determine its stock and new credit policy. According to the credit rating of the enterprise or project and the secondary analysis chart of the green category, the bank's credit policy can be divided into four categories, namely, expansion of the total amount, steady growth, adjustment structure and ratio of reduction.

- Expansion of the total amount. The green category belongs to class I, including the A1, A2, and A3 regions. Such enterprises or projects refer to emerging or traditional industries with technological advancement, representing future development trends, and enjoying the greater room for future growth, and are less affected by macroeconomic fluctuations. They should be the priority of bank development and continuously improve the total amount and proportion of credits for enterprises and projects in this category. The enterprises or projects of A1 and A2 have better qualifications, larger strength, better credit rating and more intense competition among peers. While banks are actively expanding A1 or A2 regional enterprises or projects, they also need to take various measures to focus on and support the development of A3 regional enterprises or projects.

- Steady growth. The green category belongs to category II, including the B1, B2, and B3 regions. Such enterprises or projects are mainly modern service industries or livelihood-related industries with good industrial bases, relative maturity, have great potential for sustainable development. The number of enterprises in the industry is large and they are the backbone of China's economic and industrial 
development. Such enterprises or projects account for a large proportion of credits in most banks, and their credit policies can be carried out in accordance with the previous practice. On the basis of a stable credit ratio, the credit business of such enterprises or projects is promoted to develop steadily.

- Adjustment of the structure. The green category in category III, includes the C1, C2, and C3 regions. Such enterprises or projects are, mainly, industries with low pollution and low energy consumption, or with high pollution and high energy consumption, but meeting the national energy conservation and emission reduction standards. Most of these industries belong to traditional industries, which are large in scale and account for a relatively high proportion of bank credits. Therefore, banks need to focus on the $\mathrm{C} 1$ and $\mathrm{C} 2$ regions of the enterprise based on the credit rating, to promote the steady increase of comprehensive income through the adjustment of business structures such as projects, products, investment, etc., and to implement limit management of $\mathrm{C} 3$ regional enterprises or projects credit business.

- Ratio reduction until complete withdrawal. The green category in category IV, includes the D1, D2, and D3 regions. Mainly for industries with severe overcapacity or high-pollution and high-energy enterprises, most of them have strong policy control and low development prospects. This type of credit policy should be withdrawn from the relevant national policies as soon as possible to explicitly limit and eliminate enterprises; implementing rigid limit control measures for industries with severe overcapacity, and supporting the technological upgrading, mergers, and recombination of leading enterprises with higher ratings in D1 region. For the D2 and D3 regional projects, in principle, no new ones will be added, and the stock projects will be gradually compressed and withdrawn.

4.2.3 Strengthening the internal control mechanism of green development

Set up a green development concept for the sake of value direction of green credit; establish a green credit policy, and explicate an action guide for green credit. The underlying weak internal control mechanism cannot guarantee the smooth operation of the green credit concept and policy. Therefore, the control mechanism mainly includes three aspects: internal management, internal incentives, and internal constraints:

As to internal management, after approving the bank's green credit strategy and development goals, the board of directors needs to supervise the implementation and compliance of the green credit strategy; senior management must set annual, medium- and long-term goals for implementing the green credit strategy and establish policies and procedures for implementing the green credit strategy. It will be decomposed and implemented according to regions and lines; relevant functional departments should strengthen green credit capacity building, establish and improve green credit identification and register systems, improve relevant credit management systems, and provide a basis for the implementation of internal incentives and restraint mechanisms.

As to internal incentives, banks need to set up green credit assessment indicators in the comprehensive index system for performance evaluation, conduct regular evaluations on relevant lines and branches, and increase the proportion of green credit business in the assessment when necessary. In addition, it is also possible to increase the enthusiasm for green credit business development by giving special capital support and encouraging green product development and promotion.

As to internal constraints, banks should incorporate green credit business into the scope of internal control inspection, supervise risk control in the development of green credit business; incorporate green credit system, process, and practice into internal audit, and conduct a special audit when necessary. Regardless of the major problems found in internal control compliance inspections or internal audits, rectification measures should be formulated to urge relevant departments and branches to carry out them. At the same time, banks can also actively publicize relevant information on the development of green credit business, establish communication with external sources and actively accept external supervision.

\section{Conclusion}

The development of the bank's green credit business is constrained by the status quo of China's industrial structure. Excessive emphasis on energy conservation and environmental protection business without thinking of the Chinese economy and the industrial structure itself is not conducive to the sustainable and healthy development of green credit. The Chinese government is developing specific policies to support and encourage banks to increase their enthusiasm for green credit business development. Supporting green development is also the social responsibility of banks. Therefore, in the next step of research, exploring the feasible road-map for the development of green credit business from the status quo of China's industrial structure, evolution path, and development trend will be a really meaningful issue.

\section{References}

Xiaopeng Sun. (2018). "Problems and suggestions in the development of green credit", Northern Finance, 2, 77-80.

Dexu He, Xuelan Zhang. (2007). Thoughts on Several Issues of Promoting Green Credit in China's 
Commercial Banks, Shanghai Finance, 12, 4-9.

\section{About the Author:}

Chen Jie (Huaining County, Anhui Province, China, 1983-), doctoral student, School of Public Affairs, University of Science and Technology of China, Hefei, Anhui, China, research direction: public policy management

Chen Yuee (Hefei, Anhui, China, 1983-), doctoral student, School of Public Affairs, University of Science and Technology of China, Hefei, Anhui, China, research direction: public administration

Zhang Hualun (Suzhou City, Anhui Province, China, 1984-), Ph.D., School of Public Affairs, University of Science and Technology of China, research direction: financial policy 